Nippon Suisan Gakkaishi $\quad \mathbf{8 6}(2), 102$ (2020)

\title{
ミニシンポジウム記録 魚類における不妊化研究の最前線
}

\section{4. 代理親魚技術を用いた遺伝的不妊化魚の 大量生産技術の開発}

\author{
吉浦康寿, 1 木下政人, ${ }^{2}$ 吉川廣幸 ${ }^{3}$ \\ ${ }^{1}$ 水産研究 - 教育機構瀬戸内海区水産研究所, \\ 2 京都大学農学研究科, \\ 3水産研究 · 教育機構水産大学校
}

4. Development of the mass production of genetically sterile fish using the method of surrogate broodstock

YAsuTOSHI YOSHIURA, ${ }^{1}$ MASATO KINOSHITA ${ }^{2}$

AND HIROYUKI YOSHIKAWA ${ }^{3}$

${ }^{1}$ Yashima station, Stock Enhancement and Management

Department, National Research Institute of Fisheries and

Enhancement of Inland Sea, Japan Fisheries Research and

Education Agency, Takamatsu, Kagawa 761-0111, ${ }^{2}$ Divi-

sion of Applied Bioscience, Graduate School of Agriculture,

Kyoto University, Sakyo-ku, Kyoto 606-8502, ${ }^{3}$ Department

of Applied Aquabiology, National Fisheries University,

Japan Fisheries Research and Education Agency,

Shimonoseki, Yamaguchi 759-6595, Japan

\section{1. はじめに}

標的遺伝子を効率よく改変するゲノム編集技術を水産 分野に導入することで, 優良品種が短時間で作出可能と なってきた。現在，この技術による養殖魚の品種改良が 注目されているが，実用化した場合，環境保護の観点に 掞いて，ゲノム編集魚の逃亡による野生魚との遺伝子交 雑問題は避けられない。そこで, 養殖魚の不妊化に着目 した。魚類では，三倍体化等の不妊化技術はあるもの の，いずれの方法も実用化にあたり確実性がそしい。我 々は，ゲノム編集技術を用いて $100 \%$ の不妊化が可能 な遺伝的不妊魚を作出し, その大量生産技術の開発を目 指している。

\section{2. 遺伝的不妊魚の作出}

不妊化に関わる遺伝子として, 雌では卵形成において 卵黄蓄積に必須なろ胞刺激ホルモン受容体（Fshr）を 標的とする。 $f s h r$ 欠損メダカの雌は不妊で, 雄は不妊で はないこと吕が明らかなため, 魚類における雄の不妊化 遺伝子の同定も鍵となる。そこで，精子核特有のタンパ ク質でDNAを保護するプロタミン（Prot）或いは精子 の鞭毛を構成するダイニン（Dnai1）を候補にし，両者 の精子形成における役割を解明していく。現在, トラフ
グの，第 1 世代の $f s h r$ 変異導入親魚を確保している。 この親魚から得られる第 2 世代の $f_{s} h r$ 欠損ホモ個体の 作出に成功した。さらに, Dnai1の遺伝子破壊したトラ フグの作出も試みている。

\section{3. 遺伝的不妊魚の大量生産技術の開発}

ゲノム編集で Fshr および Dnai1の遺伝子を欠損した 場合, 当然, 交配による大量生産はできない。そこで, 代理親魚法を用いた全雌の遺伝的不妊化魚だけを大量生 産する方法を考案した。既に，東京海洋大学・吉崎らと の共同研究で, メダカ $f_{s} h r$ 欠損体（ホモ不妊個体）の 生殖細胞を代理親魚へ移植し, ホモ不妊個体の大量生産 が可能であることを示した。2この系を用いて，fshr dnai1 の二重欠損体でも, 同様に遺伝的不妊魚が大量生 産できる技術を開発し，養殖対象魚のトラフグで証明し ていく。トラフグの場合は, クサフグを用いた代理親魚 法を導入する。今回は, さらにトラフグの生産効率をあ げるため, 生殖細胞のないクサフグを代理親にして, 移 植した生殖細胞由来のトラフグ卵だけを産む技術の確立 に挑む。生殖細胞のないクサフグは, 生殖細胞の発生に 不可欠な DEAD END (Dnd) 遺伝子をゲノム編集で欠 損させ，機能欠損が期待できるフレームシフト变異を持 つF1の作製（ヘテロ）に成功した。

\section{4. 今後の課題}

現在, 遺伝的不妊化魚の作出に必要な候補遺伝子に関 する情報が少ない。養殖魚へ導入する前にメダカをモデ ルとした不妊化が可能な遺伝子の探索が重要である。不 妊化のための遺伝子には, 今回のような生殖線の発達あ るいは, 生殖細胞側の発生, 分化に関与するものがあ る。今後, 様々な不妊化遺伝子が同定され, これらを組 み合わせることで, 雌雄ともに完全に不妊化が可能な技 術が開発できる。また，産業的に利用可能な生産効率の 高い代理親魚技術の開発も必要である。

\section{文献}

1) Murozumi N, Nakashima R, Hirai T, Kamei $Y$, IshikawaFujiwara T, Todo T, Kitano T. Loss of follicle-stimulating hormone receptor function causes masculinization and suppression of ovarian development in genetically female medaka. Endocrinology 2014; 155: 3136-3145.

2) Nagasawa K, Ishida M, Octavera A, Kusano K, Kezuka F, Kitano T, Yoshiura Y, Yoshizaki G. Novel method for mass producing genetically sterile fish from surrogate broodstock via spermatogonial transplantation. Biol. Reprod. 2019; 100: 535-546. 